\title{
Miranda
}

Revue pluridisciplinaire du monde anglophone /

Multidisciplinary peer-reviewed journal on the English-

speaking world

$23 \mid 2021$

Modernist Exceptions

\section{Absolutely Wonderful! British Stories in Bordeaux}

British Stories, 19 May-19 September 2021, Musée des Beaux-Arts, Bordeaux - Absolutely Bizarre ! Les drôles d'histoires de l'École de Bristol (1800-1840), 10 June-17 October 2021, Galerie des Beaux-Arts, Bordeaux

\section{Béatrice Laurent}

\section{OpenEdition}

\section{Journals}

Electronic version

URL: https://journals.openedition.org/miranda/42665

DOI: $10.4000 /$ miranda.42665

ISSN: 2108-6559

\section{Publisher}

Université Toulouse - Jean Jaurès

Electronic reference

Béatrice Laurent, "Absolutely Wonderful! British Stories in Bordeaux", Miranda [Online], 23 | 2021, Online since 13 October 2021, connection on 29 November 2021. URL: http://journals.openedition.org/ miranda/42665 ; DOl: https://doi.org/10.4000/miranda.42665

This text was automatically generated on 29 November 2021 .

\section{$\Theta \Theta \Theta \Theta$}

Miranda is licensed under a Creative Commons Attribution-NonCommercial-NoDerivatives 4.0 International License. 


\section{Absolutely Wonderful! British Stories in Bordeaux}

British Stories, 19 May-19 September 2021, Musée des Beaux-Arts, Bordeaux - Absolutely Bizarre ! Les drôles d'histoires de l'École de Bristol (1800-1840), 10 June-17 October 2021, Galerie des Beaux-Arts, Bordeaux

\section{Béatrice Laurent}

1 On September 15-17, 2021, an international conference on the British art of portraiture, co-organised by the University of Toulouse-Jean Jaurès and the University of BordeauxMontaigne, was held in Bordeaux. It was part of a more important cultural event, which included two art exhibitions.

2 The first exhibition entitled British Stories showcased Eighteenth- and nineteenthcentury works by British artists. It is a little known fact that paintings by artists as famous as Allan Ramsay, John Martin, Joshua Reynolds and Thomas Lawrence feature in the collections of Bordeaux art museum, alongside the works of their lesser-known, sometimes anonymous, contemporaries. These British paintings were given pride of honour from May until September 2021 and exhibited together with better-known works of the British school on loan from the musée du Louvre in Paris. The museological scenography aimed to encourage a 'conversation' between the two museums, but also between eighteenth and nineteenth- century British artists and their paintings. The modern approach the curators chose for this exhibition appealed to a large audience, and attracted new attention to the rich resources of this provincial museum.

3 The second exhibition took place in a venue just across the road from the musée, at the Galerie des Beaux-Arts, and focused on the early nineteenth-century works of the Bristol School of Artists. This spectacular exhibition entitled Absolutely Bizarre! Les drôles d'histoires de l'Ecole de Bristol (1800-1840) resulted from the collaboration of the Bristol Museum and Art Gallery with the musée des Beaux-Arts de Bordeaux, and offered a glimpse of the little-known and rather loose group of artists, retrospectively referred to as the Bristol School. This group includes Francis Danby, William West and their friends who, without claiming their belonging to a specific movement or school as 
such, enjoyed sketching together and painting the city they lived in. This impeccably staged exhibition presented seventy-two works on loan from the Victoria Art Gallery of Bath, the Society of Merchants Venturers in Bristol, as well as the Bristol Museum and Art Gallery and the Tate Gallery in London. The five sections of the exhibition entitled 'Absolutely Panoramic!', ‘Absolutely Social Comedy!', ‘Absolutely Nature!', 'Absolutely Sublime!', and 'Absolutely Terrible!' invited the public to navigate from one genre to another, and to gain a valuable overview of early nineteenth-century mindsets and preoccupations. This exhibition also provided a perfect opportunity to honour the partnership between Bordeaux and Bristol, which have been twin cities since 1947.

Both exhibitions took place simultaneously and were curated by a team of art experts: Guillaume Faroult, the head curator of paintings at the musée du Louvre and an authority on eighteenth-century art, Jenny Gaschke who is curator of Fine Art Pre-1900 at the Bristol Museum \& Art Gallery, Sophie Barthélémy, the director of the musée des Beaux-Arts de Bordeaux, and Sandra Buratti-Hasan, a curator at the same museum. The curatorial quartet carefully selected paintings, drawings, sculptures and other artefacts, which reflect the richness and diversity of artistic expression from the age of Enlightenment to the dawn of the twentieth century, and provide an insight of Georgian and Victorian Britain.

5 The two-day conference, which came as a climax at the end of the exhibitions, focused on portrait painting, the most representative genre in British eighteenth-century art. Indeed, while we tend to remember the age of Enlightenment in art mostly for its invention of the conversation piece, face painting, as portraiture was then called, was by far the most widely spread genre, used for the depiction of individuals or groups, in official or domestic settings, or even in fancy pictures. Portraits were the specialty of many artists, including two presidents of the Royal Academy, Sir Joshua Reynolds and Sir Thomas Lawrence, as well as the Scotsman Allan Ramsay - all represented with works from the Bordeaux musée des Beaux-Arts collections. As large fortunes were being made during the first Industrial Revolution, portraits became increasingly fashionable as status symbols, as well as national statements of authority and identity. Indeed, so popular was portraiture as a genre that it threatened the supremacy of history painting in the stratified definition of High Art, and called for new descriptions of the functions and purposes of artworks.

With the opening of the National Portrait Gallery in London in 1856, the importance of face painting became legitimate, and a British exception since the NPG was the first museum worldwide wholly dedicated to this particular genre. Royal and court portraits were traditionally intended as public exhibits. Following this example, many of the portraits commissioned by aristocrats and wealthy merchants steadily progressed in the eighteenth century from family mementoes to statements of dignity, yet the Romantic influence directed the trend in portraiture in the opposite direction. This bifurcation created a tension, which affected the genre well into the nineteenth century. With Queen Victoria, portraits became instruments of propaganda. The bestknown portraits of the Queen as a young Monarch, a happy mother, a sorrowful widow, as the embodiment of Britain, or of the Empire, very often commissioned by herself, were reproduced by the means of engraving, making rather cheap reproductions accessible to the majority of people, not only in Britain, but throughout the world. Then of course, from the mid-nineteenth century onwards, there were photographic portraits, which seemed to compete with painted ones and forced portrait painters to 
adapt their medium and focus maybe less on the likeness of the model, and more on other aspects such as compositions, chromatic arrangements, and handling techniques. By moving the emphasis from the surface of the skin, hair, dress, and canvas, to the depth of the sitter's character and emotions, late nineteenth- and early twentiethcentury portrait painters provided a new definition of the genre.

7 The Bordeaux exhibitions, though not wholly dedicated to portraiture, included many individual and group portraits, thus providing a most coherent and pleasurable framework for the conference.

INDEX

Mots-clés: art britannique, art du portrait, britannicité, conversation

Keywords: British art, portraiture, Britishness, conversation

Subjects: British art

\section{AUTHORS}

\section{BÉATRICE LAURENT}

Professor of Victorian Studies

Université Bordeaux-Montaigne

beatrice.laurent@u-bordeaux-montaigne.fr 